Excision of the lump to determine the malignancy grade, lymphoplasmocytic infiltration, and vascular invasion within the primary tumour will improve the prognostic accuracy, as will premastectomy axillary node biopsy to confirm gross disease of axillary nodes. Some or all of these factors may be combined to indicate a high likelihood of occult metastases in some patients who could be considered for staging laparotomy before primary treatment.

This work was supported by the Breast Cancer Research Trust.

Requests for reprints should be addressed to: J Meirion Thomas,

Royal Marsden Hospital, Downs Road, Sutton, Surrey.

\section{References}

${ }^{1}$ Fisher, B et al, Annals of Surgery, 1968, 168, 337.

Tormey, D C, Cancer, 1975, 36, 881.

3 Taylor, K J W, Carpenter, D A, and McCready, V R, fournal of Clinical Ultrasound, 1973, 1, 284.

${ }^{4}$ Fisher, B, Carbone, P, and Economa, S G, New England fournal of Medicine, 1975, 292, 117.

${ }^{5}$ Bonadonna, G, et al, New England Fournal of Medicine, 1976, 294, 405.

${ }^{6}$ Bonadonna, G, International fournal of Radiotherapy and Oncology, 1977, $2,237$.

7 Glees, J, et al, Lancet, 1978, 1, 210.

(Accepted 28 April 1978)

\title{
Comparison of performance of various sphygmomanometers with intra-arterial blood-pressure readings
}

\author{
S N HUNYOR，J M FLYNN， C COCHINEAS
}

British Medical fournal, 1978, 2, 159-162

\section{Summary and conclusions}

Seven types of sphygmomanometer were used in random order on each of nine hypertensive patients and the readings compared with simultaneous intra-arterial blood-pressure recordings. All the devices gave significantly different values for systolic pressure, and only two measured diastolic pressure without significant error. Systolic pressure was consistently underestimated (range 31-7 $\mathrm{mm} \mathrm{Hg}$ ), and all but one instrument overestimated diastolic pressure (range $10-2 \mathrm{~mm} \mathrm{Hg}$ ). The variability of readings was least with the standard mercury sphygmomanometer and the random-zero machine, while with some of the more automated devices single readings were in error up to $-68 / 33 \mathrm{~mm} \mathrm{Hg}$.

The strong correlations found between intra-arterial and cuff systolic pressures with all devices tested and significant correlations for diastolic pressure with all but one device indicate that, with one possible exception, the sphygmomanometers would give accurate results where a change in blood pressure was the main concern.

\section{Introduction}

Indirect measurement of blood pressure is undertaken with many more-or-less automated devices whose performance characteristics are poorly documented. In some cases the principle of their operation is not stated and it may not be clear whether they use phase IV or phase V of the Korotkoff sounds for the diastolic end-point. This second factor is highly relevant in exercise, pregnancy, and other high-output states. Reports on antihypertensive and vasoactive agents increasingly refer to automated sphygmomanometers that can provide results in hard-copy form. ${ }^{1-3}$ They imply that eliminating the

NH and MRC Unit for Cardiovascular Research, Department of Cardiology, Royal North Shore Hospital, St Leonards, NSW, 2065, Australia

S N HUNYOR, FRACP, FACC, research specialist in cardiology

J M FLYNN, MB, BS, renal registrar

C COCHINEAS, research technician

human observer has preserved or even increased the accuracy of the traditional sphygmomanometer.

Labarthe et $a l^{4}$ assessed the performance characteristics of various sphygmomanometers but did not use direct readings as a basis for comparison and omitted newer, simple, and relatively cheap semiautomatic devices, some of which are aimed at selfmeasurement. Several newer devices have features such as audiovisual signalling of end-points, adjustable preset deflation rate, elimination of observer bias and error, and results in hardcopy form. Any of these features may make one or other model the instrument of choice for particular purposes, such as selfmeasurement of blood pressure, semiautomated pressure monitoring, epidemiological surveys, or assessment of antihypertensive agents, provided that a given standard of accuracy can be assumed or demonstrated.

We have tested a sample of sphygmomanometers, including the common clinical mercurial model, which varied widely in cost and the amount of training needed by users. They represented mercurial and aneroid models based on human detection of Korotkoff sounds, sound filters, and an ultrasound principle. The study was designed to correspond to everyday clinical application and we did not consider the ease of use or accuracy of the instruments in untrained hands.

\section{Materials and methods}

We used seven different types of sphygmomanometer (see table I) in random order on nine patients aged $25-80$ years, while simultaneously recording direct intra-arterial blood pressure. The patients were receiving various drug regimens for hypertension and presented a range of blood pressure levels. All gave consent to the study. One patient (case 1) had frequent ventricular ectopic beats, and one other (case 9) was in controlled atrial fibrillation.

Supine blood pressure was taken as the average of two readings, phase $\mathrm{V}$ being used as the diastolic end-point when observer auscultation was used. In one patient (case 2) there was no disappearance of sounds down to zero, and in this case muffling (phase IV) was used for the diastolic end-point. Intra-arterial pressure was determined as the average of 15 complexes immediately preceding cuff inflation.

The blood-pressure cuff was applied to the arm containing a $50 \mathrm{~mm}$ 17-gauge Teflon cannula (Dwellcath, TUTA Laboratories, Lane Cove, Australia) inserted into the brachial artery. Intra-arterial blood pressure was measured by a Siemens model 746 pressure transducer and a Philips amplifier type XV 1505, direct calibration of the system being carried out on the day of the procedure. The resonant frequency of the whole system was $13.8 \mathrm{~Hz}$ with a damping factor of $0 \cdot 37$. Zero reference level was taken as midthorax in the supine position and was 
checked before and after each reading. Direct pressures were read from the record by one of us without being aware of the sphygmomanometer readings.

All the cuffs used had bladders $120-135 \mathrm{~mm}$ wide and 220-230 $\mathrm{mm}$ long. In the case of the four electronic instruments the manufacturers' cuffs were used as they contained a built-in sensor with or without a stimulator. Mid-arm circumference was measured in each case.

\section{DEVICES TESTED}

The four more-or-less automated devices evaluated were the Arteriosonde 1217, Kenz-45, Cardy 8, and I-Health. Two manual models in addition to the standard mercury sphygmomanometer (Accoson) were tested-namely the London School of Hygiene and Hawksley Random-Zero machines. These two instruments minimise observer bias, the London School of Hygiene machine also obviating digit preference. Table I lists the specifications and characteristics of the devices.

Arteriosonde (1216 and 1217)-This instrument employs an ultrasound principle for detecting arterial wall motion. It is claimed to exclude many interfering artefacts and to be especially useful for measuring low blood pressures, when the regular Korotkoff sounds may be misleading. ${ }^{5}{ }^{6}$ It can be programmed to measure blood pressure at set intervals and can provide a hard copy of results.

Kenz-45-This device detects Korotkoff sounds using band-pass filters with frequency peaks said to be appropriate to systolic ( 40 and $80 \mathrm{~Hz}$ ) and diastolic phase $\mathrm{V}$ pressures $(80 \mathrm{~Hz})$. It provides a digital read-out of blood pressure and can be set "blind" so that values are stored in a memory.

Cardy 8 and I-Health-Both these instruments employ auditory as well as visual signals to permit identification of Korotkoff sounds. The sphygmomanometers are of aneroid type and are compact and battery operated. Their use requires minimal expertise and training, and, combined with the ease of cuff application (straps plus Velcro fastners), they lend themselves to home use by laymen.

London School of Hygiene and Hawksley Random-Zero machinesGood descriptions of these specialised instruments are available ${ }^{78}$ and point to their principal role in epidemiological surveys and therapeutic trials, where the question of observer bias is most important.

\section{STATISTICAL ANALYSIS}

Two-way analysis of variance with replication, ${ }^{9}$ Student's $t$ test (paired samples), and linear regression analysis were used.

\section{Results}

The readings obtained with all the sphygmomanometers tested differed significantly from the intra-arterial pressures (table II). On the basis of a two-way analysis of variance (fixed-effects model) with replication the machine effect gave the largest variance ratio for differences $(\triangle)$ in systolic $(F=28.46)$ and diastolic $(F=10 \cdot 15)$ pressures, but interaction $(\triangle$ systolic $-F=3.08 ; \triangle$ diastolic $-F=$ 3.55), and patient effects $(\triangle$ systolic- $F=9.39 ; \triangle$ diastolic $-F=$ 7.96) were also significant. In general all indirect methods tested underestimated systolic pressure and overestimated diastolic pressure (table II). The main exceptions were the Cardy 8, which tended to underestimate diastolic as well as systolic pressure, and the London School of Hygiene and I-Health instruments, which accurately determined diastolic pressure.

The most consistent readings of systolic pressure were obtained with the London School of Hygiene and Accoson models (coefficients of variation of difference $-30^{\circ}$ and $-34^{\circ}$ a respectively) and of diastolic pressure with the Accoson and Hawksley Random-Zero machines (coefficients of variation $67 \%$ and $88 \%$ respectively). The greatest variation in readings, when both systolic and diastolic pressures are taken into account, occurred with the I-Health and Cardy 8. When measuring systolic pressure all machines showed highly significant correlations with direct readings (figure). Correlations with intra-arterial diastolic pressures were more variable, but only with the Cardy 8 was the coefficient not significant.

Variations in mid-arm diameters $(73-111 \mathrm{~mm})$ did not influence the accuracy of the various instruments, although only in case 4 did the patient's arm diameter exceed the recommended maximum for the size of cuffs used (cuff width should exceed mid-arm diameter by $\left.20 \%{ }^{10}\right)$.

Isolated gross aberrations tended to occur with the automated devices even though their average error for systolic and diastolic pressure readings was not necessarily greater than that of the manual models (table II). When we examined individual readings rather than the average of duplicates as given in table II, we found the Accoson to have by far the smallest maximum single error $(-19 / 18 \mathrm{~mm} \mathrm{Hg})$, whereas with the Arteriosonde one reading was out by $-68 / 33 \mathrm{~mm}$ $\mathrm{Hg}$. The large systolic errors with the Arteriosonde seemed to be related to premature triggering of a control designed to prevent mercury spilling out of the top of the column during autoinflation.

\section{Discussion}

Since Labarthe $e t a l^{4}$ examined the performance characteristics of various sphygmomanometers many smaller semiautomated devices have become available at prices that patients can afford. Many of the machine criteria assessed by Labarthe et al or recommended as desirable for epidemiological use by a task force committee ${ }^{11}$ are of little relevance when a device is used by a patient to assess his own antihypertensive treatment. Nevertheless, many of the cautions of those workers concerning substitution of machine dependence for observer dependence still stand.

We used the standard mercury sphygmomanometer as a

TABLE I-Specifications of sphygmomanometers tested

\begin{tabular}{|c|c|c|c|c|c|c|c|}
\hline & $\begin{array}{l}\text { Accoson } \\
\text { (standard) }\end{array}$ & $\begin{array}{c}\text { London School of } \\
\text { Hygiene }\end{array}$ & $\begin{array}{c}\text { Hawksley random } \\
\text { Zero }\end{array}$ & Kenz-45 & Cardy 8 & I-Health & $\begin{array}{l}\text { Arteriosonde } \\
1216(110 \mathrm{~V}) \\
\text { or } 1217(240 \mathrm{~V})\end{array}$ \\
\hline Measuring range & $0-300$ & $0-280$ & $0-240(300)^{*}$ & $10-285$ & $0-300$ & $0-300$ & $0-256$ \\
\hline $\begin{array}{l}\text { (mm Hg) } \\
\text { Manometer type } \\
\text { Observer bias }\end{array}$ & $\begin{array}{l}\mathrm{Hg} \\
\text { No allowance }\end{array}$ & $\begin{array}{l}\mathrm{Hg} \\
\text { Eliminates digit } \\
\quad \text { preference, } \\
\text { observer bias }\end{array}$ & $\begin{array}{c}\mathrm{Hg} \\
\text { Eliminates some } \\
\text { observer bias }\end{array}$ & $\begin{array}{l}\text { Aneroid } \\
\text { Eliminates digit } \\
\text { preference, } \\
\text { observer bias }\end{array}$ & $\begin{array}{l}\text { Aneroid } \\
\text { No allowance }\end{array}$ & $\begin{array}{l}\text { Aneroid } \\
\text { No allowance }\end{array}$ & $\begin{array}{l}\mathrm{Hg} \\
\text { Observer bias } \\
\text { largely overcome } \\
\text { only with hard } \\
\text { copy }\end{array}$ \\
\hline $\begin{array}{l}\text { Hard-copy result } \\
\text { Autoinflation/ } \\
\text { controlled deflation }\end{array}$ & & Gas cylinder/yes & No/yes & $\begin{array}{l}\text { Optional } \\
\text { Electric pump/ } \\
\text { yes }\end{array}$ & & & $\begin{array}{l}\text { Optional } \\
\text { Electric pump/ } \\
\text { yes }\end{array}$ \\
\hline $\begin{array}{l}\text { Korotkoff-sound- } \\
\text { based }\end{array}$ & Yes & Yes & Yes & Yes & Yes & Yes & No (ultrasound) \\
\hline $\begin{array}{l}\text { Diastolic reading } \\
\text { criterion } \\
\text { (Korotkoff phase) }\end{array}$ & IV, V & IV, V & IV, V & $\mathrm{V}$ & $\mathrm{V}$ & $\mathrm{V}$ & IV \\
\hline $\begin{array}{l}\text { Auditory dependence } \\
\text { Weight of unit (kg) } \\
\text { Power required }\end{array}$ & $\begin{array}{l}\text { Yes } \\
1.5\end{array}$ & $\begin{array}{l}\text { Yes } \\
14 \cdot 9\end{array}$ & $\begin{array}{l}\text { Yes } \\
3 \cdot 75\end{array}$ & $\begin{array}{l}\text { No } \\
6 \cdot 8 \\
\text { AC }\end{array}$ & $\begin{array}{l}\text { No } \\
0 \cdot 5 \\
\text { Battery }\end{array}$ & $\begin{array}{l}\text { No } \\
1 \cdot 6 \\
\text { Battery }\end{array}$ & $\begin{array}{l}\text { No } \\
18 \cdot 4 \\
\text { AC }\end{array}$ \\
\hline Unit cost $(\$ A)(1977)$ & 25 & 750 & 500 & 1300 & 80 approx & 100 approx & $\begin{array}{l}\text { Basic unit } 4906 \text {; } \\
2355 \text { extra for } \\
\text { hard copy }\end{array}$ \\
\hline $\begin{array}{l}\text { User or technical } \\
\text { manual/literature }\end{array}$ & $\underset{\text { extensive }}{\text { Minimal/ }}$ & Good/good & Good/good & $\begin{array}{l}\text { Not adequate/ } \\
\text { nil (?) }\end{array}$ & $\underset{\text { nil (?) }}{\operatorname{Minimal} /}$ & $\underset{\text { nil (?) }}{\operatorname{Minimal} /}$ & $\begin{array}{l}\text { Excellent/ } \\
\text { extensive }\end{array}$ \\
\hline
\end{tabular}


TABLE II-Comparative performance of seven sphygmomanometers with simultaneous intra-arterial readings in nine patients. Cuff (indirect) pressures are means of two readings: intra-arterial pressures are means of 15 complexes. All readings (systolic diastolic) expressed in $\mathrm{mm} \mathrm{Hg}$

\begin{tabular}{|c|c|c|c|c|c|c|c|c|c|c|c|c|}
\hline & & Case No: & 1 & 2 & 3 & 4 & 5 & 6 & 7 & 8 & 9 & Mean $=\mathrm{SD}$ \\
\hline \multicolumn{3}{|c|}{$\begin{array}{l}\text { Cuff bladder width } \div \text { : } \\
\text { mid-upper-arm diameter: }\end{array}$} & $1 \cdot 81$ & 1.60 & 1.55 & $1 \cdot 19$ & $1 \cdot 73$ & 1.49 & $1 \cdot 45$ & 1.49 & $1 \cdot 60$ & $1 \cdot 55 \div 0 \cdot 17$ \\
\hline \multicolumn{13}{|c|}{ Accoson (standard) } \\
\hline $\begin{array}{l}\text { Intra-arterial } \\
\text { Cuff } \quad \ldots\end{array}$ & . & $\begin{array}{l}\cdots \\
\cdots\end{array}$ & $\begin{array}{l}24492 \\
236,103\end{array}$ & $\begin{array}{l}22180 \\
210.87\end{array}$ & $\begin{array}{l}15086 \\
13994\end{array}$ & $\begin{array}{l}16476 \\
15886\end{array}$ & $\begin{array}{ll}242 & 126 \\
230 & 120\end{array}$ & $\begin{array}{l}15481 \\
13888\end{array}$ & $\begin{array}{l}13774 \\
12780\end{array}$ & $\begin{array}{l}17575 \\
17090\end{array}$ & $\begin{array}{l}147 / 102 \\
137 / 116\end{array}$ & $\begin{array}{l}181 / 88+40 \cdot 0 / 15 \cdot 9 \\
172 / 96 \div 40 \cdot 3 / 13 \cdot 2\end{array}$ \\
\hline \multicolumn{3}{|c|}{ Difference } & -810 & -118 & -118 & 610 & $-12-5$ & 177 & -106 & $-5 / 15$ & $-9: 14$ & $-10 * * * / 8 * * 3 \cdot 3 / 5 \cdot 5$ \\
\hline \multicolumn{13}{|c|}{ London School of Hygiene machine } \\
\hline $\begin{array}{l}\text { Intra-arterial } \\
\text { Cuff } \quad \ldots\end{array}$ & $\begin{array}{l}. \\
\cdots\end{array}$ & . & $\begin{array}{l}24089 \\
21790\end{array}$ & $\begin{array}{l}22081 \\
19577\end{array}$ & $\begin{array}{l}14884 \\
13387\end{array}$ & $\left|\begin{array}{l}16777 \\
14880\end{array}\right|$ & \begin{tabular}{ll|}
248 & 127 \\
211 & 116
\end{tabular} & $\begin{array}{l}14979 \\
13281\end{array}$ & $\begin{array}{l}12969 \\
11273\end{array}$ & $\begin{array}{l}18383 \\
16790\end{array}$ & $\begin{array}{l}14991 \\
128111\end{array}$ & $\begin{array}{l}181 / 87: 41 \cdot 5 / 15 \cdot 5 \\
160 / 89: 36 \cdot 7 / 14 \cdot 0\end{array}$ \\
\hline \multicolumn{3}{|c|}{ Difference } & -231 & $-25-4$ & -154 & -194 & $-37-11$ & $-17 / 2$ & -174 & -178 & $-21 / 20$ & $-21^{* * *} / 3(\mathrm{NS}): 6 \cdot 4 / 7 \cdot 9$ \\
\hline \multicolumn{13}{|c|}{ Hawksley Random-Zero machine } \\
\hline $\begin{array}{l}\text { Intra-arterial } \\
\text { Cuff } \ldots\end{array}$ & $\therefore$ & $\begin{array}{l}\cdots \\
\cdots\end{array}$ & $\begin{array}{l}23796 \\
21389\end{array}$ & $\begin{array}{l}22283 \\
21697\end{array}$ & $\begin{array}{l}14781 \\
14089\end{array}$ & \begin{tabular}{|l|}
17280 \\
15484
\end{tabular} & \begin{tabular}{ll|}
247 & 130 \\
261 & 145
\end{tabular} & $\begin{array}{l}15584 \\
15292\end{array}$ & $\begin{array}{l}13373 \\
13483\end{array}$ & $\begin{array}{l}18082 \\
17495\end{array}$ & $\begin{array}{l}148 / 101 \\
138 / 102\end{array}$ & $\begin{array}{l}182 / 90=40 \cdot 1 / 16 \cdot 2 \\
175 / 97=41 \cdot 8 / 17.8\end{array}$ \\
\hline \multicolumn{3}{|c|}{ Difference } & $-24-7$ & 614 & -78 & -184 & 1516 & -49 & 110 & -613 & -102 & $-7^{* *} / 8^{* *} 10 \cdot 4 / 6 \cdot 7$ \\
\hline \multicolumn{13}{|c|}{ Kenz-45 } \\
\hline $\begin{array}{l}\text { Intra-arterial } \\
\text { Cuff } \quad \ldots\end{array}$ & $\begin{array}{l}\cdots \\
\cdots\end{array}$ & $\begin{array}{l}\cdots \\
\cdots\end{array}$ & $\begin{array}{l}24693 \\
238100\end{array}$ & $\begin{array}{l}22481 \\
21274\end{array}$ & $\begin{array}{l}14880 \\
13594\end{array}$ & $\begin{array}{l}17080 \\
15190\end{array}$ & $\begin{array}{ll}251 & 124 \\
221 & 117\end{array}$ & $\begin{array}{l}15081 \\
13689\end{array}$ & $\begin{array}{l}14879 \\
13795\end{array}$ & $\begin{array}{l}17275 \\
15994 \\
\end{array}$ & $\begin{array}{l}145 / 100 \\
145 / 128\end{array}$ & $\begin{array}{l}184 / 88+41 \cdot 6 / 14 \cdot 7 \\
170 / 98 \pm 38 \cdot 8 / 15 \cdot 0\end{array}$ \\
\hline \multicolumn{3}{|c|}{ Difference } & 87 & $\begin{array}{r}-127 \\
\end{array}$ & -1314 & $-19: 10$ & -308 & -159 & -1116 & -1419 & $0 / 28$ & $-14^{* * *} / 10^{* * *} 7 \cdot 7 / 11 \cdot 0$ \\
\hline \multicolumn{13}{|c|}{ Cardy 8} \\
\hline $\begin{array}{l}\text { Intra-arterial } \\
\text { Cuff } \quad \ldots \\
\end{array}$ & $\begin{array}{l}\cdots \\
\cdots \\
\end{array}$ & $\begin{array}{l}. \\
\therefore\end{array}$ & $\begin{array}{l}24499 \\
23585 \\
\end{array}$ & $\begin{array}{l}21478 \\
20640\end{array}$ & $\begin{array}{l}15588 \\
14890 \\
\end{array}$ & $\begin{array}{l}177.83 \\
17380 \\
\end{array}$ & $\begin{array}{l}245,126 \\
217112\end{array}$ & $\begin{array}{r}15080 \\
13276 \\
\end{array}$ & $\begin{array}{l}13773 \\
12776 \\
\end{array}$ & $\begin{array}{l}16873 \\
16085\end{array}$ & $\begin{array}{l}13796 \\
134103 \\
\end{array}$ & $\begin{array}{r}18188+40 \cdot 6 / 15 \cdot 9 \\
170 / 83 \div 37 \cdot 9 / 19 \cdot 0 \\
\end{array}$ \\
\hline \multicolumn{3}{|c|}{ Difference } & $-9 \quad 13$ & $8 \cdot 38$ & -83 & $-4-3$ & $-28-14$ & $-18-5$ & -103 & -88 & -38 & $-11^{* * *} /-6^{* *}: 7 \cdot 3 / 13 \cdot 7$ \\
\hline \multicolumn{13}{|c|}{ I-Health } \\
\hline $\begin{array}{l}\text { Intra-arterial } \\
\text { Cuff } \quad \ldots\end{array}$ & $\begin{array}{l}\cdots \\
\cdots\end{array}$ & $\begin{array}{l}\cdots \\
\cdots\end{array}$ & $\begin{array}{l}24191 \\
22393 \\
\end{array}$ & $\begin{array}{l}22888 \\
20382 \\
\end{array}$ & $\begin{array}{l}15585 \\
14889 \\
\end{array}$ & $\begin{array}{l}17281 \\
14580 \\
\end{array}$ & $\begin{array}{l}258127 \\
229115 \\
\end{array}$ & $\begin{array}{l}15782 \\
14162\end{array}$ & $\begin{array}{l}13070 \\
12578\end{array}$ & $\begin{array}{l}165 / 70 \\
160 / 87\end{array}$ & $\begin{array}{l}149 / 102 \\
140 / 111\end{array}$ & $\begin{array}{l}184 / 88+43 \cdot 3 / 16 \cdot 7 \\
168 / 89: 37 \cdot 0 / 15 \cdot 5\end{array}$ \\
\hline \multicolumn{3}{|c|}{ Difference } & -182 & 259 & -75 & $-27-1$ & $-29-8$ & $-16-20$ & -59 & $-5 / 17$ & -910 & $-16^{* * *} 2(\mathrm{NS})+9 \cdot 1 / 10 \cdot 2$ \\
\hline \multicolumn{13}{|c|}{ Arteriosonde 1217} \\
\hline $\begin{array}{l}\text { Intra-arterial } \\
\text { Cuff } \quad \ldots\end{array}$ & . & $\begin{array}{l}\cdots \\
\cdots\end{array}$ & $\begin{array}{l}262 \quad 102 \\
231 \quad 114\end{array}$ & $\begin{array}{l}20477 \\
17491\end{array}$ & $\begin{array}{l}15188 \\
12692\end{array}$ & \begin{tabular}{l|}
17580 \\
13567
\end{tabular} & \begin{tabular}{ll|}
261 & 151 \\
202 & 163
\end{tabular} & $\begin{array}{l}14275 \\
10879\end{array}$ & $\begin{array}{l}14074 \\
12683\end{array}$ & $\begin{array}{l}17173 \\
15577\end{array}$ & $\begin{array}{l}150106 \\
12695\end{array}$ & $\begin{array}{l}184 / 92: 45 \cdot 5 / 23 \cdot 9 \\
154 / 96: 38 \cdot 7 / 26 \cdot 9\end{array}$ \\
\hline \multicolumn{3}{|c|}{ Difference } & -3212 & $-30: 14$ & -255 & $-40 \cdot 13$ & -5912 & -344 & -149 & -164 & $-25-11$ & $-31 * * * / 4 *+12 \cdot 7 / 9 \cdot 2$ \\
\hline
\end{tabular}

$* \mathrm{P}<0.05 . \quad * * \mathrm{P}<0.01 . \quad * * * \mathrm{P}<0.001 . \quad \mathrm{NS}=$ Not significant.

basis for comparison and compared sophisticated instruments such as the Arteriosonde 1216/1217 and Kenz-45 with some newer, small semiautomated and relatively cheap Korotkoffsound-filtering devices. We thought it essential to match performance against direct intra-arterial readings because when sphygmomanometers are used in treated hypertensive patients, as in this study, the direct-indirect relations may be different from those hitherto described ${ }^{12-14}$ owing to possible shifts in the frequency spectrum of the Korotkoff sounds. ${ }^{15}$

Comparison with direct readings showed the standard sphygmomanometer to underestimate systolic pressure by a mean of $10=\mathrm{SD} 3.3 \mathrm{~mm} \mathrm{Hg}(\mathrm{n}=9)$ and to overestimate diastolic pressure (phase $\mathrm{V}$ ) by a mean of $8 \div 5.5 \mathrm{~mm} \mathrm{Hg}$ (n 9). These values correspond closely to the results of Breit and O'Rourke, ${ }^{14}$ who also studied a group with vascular disease (myocardial infarction). The theoretical considerations of Maurer and Noordergraaf ${ }^{15}$ would also predict this type of result with indirect measurements.

We used the disappearance (phase V) of the Korotkoff sounds as the diastolic end-point in this study, partly because a clear phase IV could not be detected in most patients. Since we found that the standard sphygmomanometer overestimated the diastolic pressure phase IV would have been less accurate. Most automated devices are set to detect disappearance of sound, which seems reasonable since mortality and morbidity data from life insurance firms and the Framingham and other studies $^{16-19}$ refer to Korotkoff phase V. Nevertheless, in certain specific cases the ability to measure phase $\mathrm{V}$ alone may mislead -for example, during pregnancy, during and after exercise, or in children, where high flow rates may exist. ${ }^{10}$

In our study all seven sphygmomanometers tested gave significantly different values from the intra-arterial readings for either systolic or both systolic and diastolic pressures. The only readings that did not differ from direct values were the diastolic pressures obtained with the London School of Hygiene and I-Health machines. The standard sphygmomanometer showed the smallest scatter of readings about the mean for systolic pressure and shared this distinction with the Hawksley Random-Zero machine for diastolic pressure.

The correlation of indirect systolic pressure with the intraarterial level was highly significant with each of the seven machines (figure). Thus when changes in blood pressure are of prime importance-for example, in assessing the efficacy of antihypertensive agents-indirect readings would give a faithful record of events. A significant but weaker correlation with intra-arterial diastolic pressure was also found for all machines (figure) except the Cardy 8.

The resonant frequency of the direct pressure-recording system was such that a significant overestimation of true systolic pressure or underestimation of true diastolic pressure was most unlikely. Thus the difference between direct and indirect readings must indicate a true limitation in performance characteristics of the sphygmomanometers. Probably these limitations would be highlighted under more difficult conditions of blookpressure measurement (for example, exercise or pregnancy), particularly with those instruments capable of detecting only the phase $\mathrm{V}$ diastolic end-point.

Since we tested only one of each type of instrument possibly our machines were not representative. All the devices were virtually new, however, except for the London School of Hygiene machine; this had been extensively serviced, resulting in stiffness of the plungers, which could have contributed to the underestimation of systolic pressure. The Arteriosonde seemed to be incapable of handling a systolic pressure above $240 \mathrm{~mm} \mathrm{Hg}$ 
despite a specified maximum of $256 \mathrm{~mm} \mathrm{Hg}$, and the largest errors with it occurred in that region. Moreover, we used only one observer and a small group of patients, though these were chosen to represent a range of ages and blood pressure levels. Thus the degree of inaccuracy we found with a particular machine might not apply in all circumstances, but the trends of performance are likely to be generally valid.

The effect of cuff size on the accuracy of blood-pressure determination was negligible. The American Heart Association
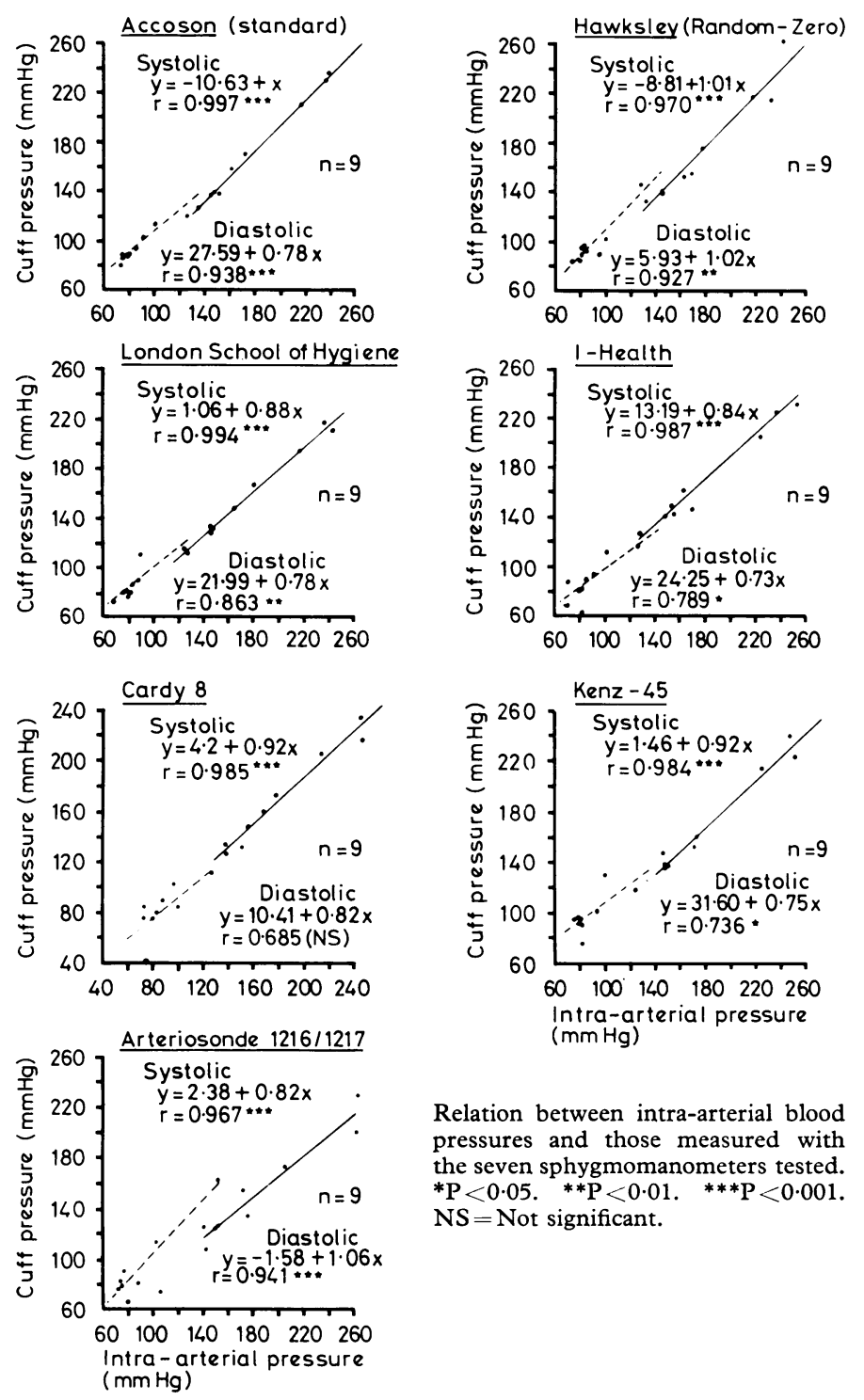

Relation between intra-arterial blood pressures and those measured with the seven sphygmomanometers tested. $* \mathrm{P}<0.05$. **P<0.01. *** $\mathrm{P}<0.001$ $\mathrm{NS}=$ Not significant. recommendation ${ }^{10}$ for cuff width was fulfilled in all but one of our patients (case 4), whose mid-upper-arm diameter exceeded 1.2 times cuff width (table II). Apparently the question of arm girth or length is relevant only in children and the very obese. ${ }^{20}$

Our findings suggest that all seven types of sphygmomanometer tested have shortcomings in accuracy, even when they are used by an experienced observer, if compared with simultaneous intra-arterial readings. Indirect figures, however, mirror changes in blood pressure more accurately than absolute levels, and there were strong correlations between the two methods of measurement for systolic and to a less extent diastolic pressure except with the Cardy 8 machine. The errors from sphygmomanometers were mostly small, especially for diastolic pressure, but with two instruments mean variations in systolic pressure approached $20-30 \mathrm{~mm} \mathrm{Hg}$ (table II). Such an error in systolic pressure could mean that hypertensive patients are incorrectly categorised or the effect of treatment misinterpreted.

This work was supported by a grant from the National Health and Medical Research Council and by the Royal North Shore Hospital of Sydney. We thank Geraldine Ketteridge and Charlotte Hartyanszky for the typing and illustrations, and B Bagley, SRN, and M Ross, SRN, for valuable work. Dr J Baker and Dr H M Hudson helped with the statistical analyses.

Requests for reprints should be addressed to: Dr Stephen $\mathrm{N}$ Hunyor, Department of Cardiology, Royal North Shore Hospital, St Leonards, NSW, 2065, Australia.

\section{References}

${ }^{1}$ MacGregor, G A, and Dawes, P M, Clinical Science and Molecular Medicine, 1976, 51, 1935.

2 Wester, A, et al, Clinical Science and Molecular Medicine, 1976, 51, 6055.

${ }^{3}$ Brunner, H R, et al, Progress in Biochemical Pharmacology, 1976, 12, 145.

${ }^{4}$ Labarthe, D R, Hawkins, C M, and Remington, R D, American fournal of Cardiology, 1973, 32, 546.

${ }^{5}$ Sheppard, L C, Johnson, T S, and Kirklin, J W, fournal of the Association for Advancement of Medical Instrumentation, 1971, 5, 297.

${ }^{6}$ Gundersen, J, and Ahlgren, I, Acta Anaesthesiologica Scandinavica, 1973 17, 203.

${ }^{7}$ Rose, G A, Holland, W W, and Crowley, E A, Lancet, 1964, 1, 296.

8 Wright, B M, and Dore, C F, Lancet, 1970, 1, 337.

${ }^{9}$ Scheffe, H, The Analysis of Variance, p 90. New York, Wiley and Sons Inc, 1959.

${ }^{10}$ Kirkendall, W M, et al, Circulation, 1967, 36, 980.

11 Feinleib, M, et al, Circulation, 1974, 49, 6.

${ }^{12}$ Holland, W W, and Humerfelt, S, British Medical fournal, 1964, 2, 1241.

${ }_{13}$ Raftery, E B, and Ward, A P, Cardiovascular Research, 1968, 2, 210.

${ }^{14}$ Breit, S N, and O'Rourke, M F, Australian and New Zealand Fournal of Medicine, 1974, 4, 485.

${ }_{15}$ Maurer, A H, and Noordergraaf, A, American Heart fournal, 1976, 91, 584.

16 Veterans Administration Co-operative Study Group on Antihypertensive Agents 2, Fournal of the American Medical Association, 1967, 202, 1028

17 Remington, R D (for the hypertension detection and follow-up program investigators), INSERM, 1973, 21, 185.

18 Hunyor, S N, et al, Medical fournal of Australia, 1977, 1, 517.

19 Peart, W S, et al, British Medical fournal, 1977, 1, 1437.

${ }^{20}$ Steinfeld, L, Alexander, H, and Cohen, M L, American fournal of Cardiology, 1974, 33, 107.

(Accepted 2 May 1978)
ONE HUNDRED YEARS AGO The Women's Society for Succouring the Sick and Wounded, established in Germany under the protection and patronage of the Empress Augusta, recently held its second meeting in Dresden. The assembly was attended by one hundred and seventy-one delegates, of whom one hundred and twenty-four were ladies and forty-seven gentlemen, from Dresden, Berlin, Leipsic, Magdeburg, Würzburg, and other German towns, and also by the Empress herself and by the Queen of Saxony, the founder of the Albert Society established in Dresden. A paper was read on the occasion by the surgeon-general of the Saxon Army Corps, on the working of voluntary societies for tending the sick, in which it was mentioned that during the Franco-German war of 1870-71, 54000000 marks were spent by these societies, and that 149000 sick and wounded passed through the station at Nancy. An accoun was then given of the work done during the late Turco-Russian war, in Constantinople and Bucharest, by the members of the Saxon Albert Society; the speaker declaring, according to the report of the proceedings, with much animation and eloquence, that it was thanks to the kindly zeal, untiring energy, and careful forethought of Her Majesty Queen Carola that it had been possible for the Society to carry out its Christian and philanthropic work on the shores of the distant Bosphorus. At the close of the proceedings, the Empress, in the name of the German Society, thanked the Queen for the invitation to meet at Dresden, and for the interest she had manifested in its welfare. (British Medical fournal, 1878.) 